\title{
A REVISION OF THE NEARCTIC SPECIES OF
}

\section{TOMODERUS (COLEOPTERA: ANTHICIDAE)}

\author{
BY F. G. WERNER
}

University of Arizona, Tucson

The Nearctic species of Tomoderus are very similar to each other in general appearance and present a perplexing problem both taxonomically and nomenclatorially. When Say described the first species, constrictus, he mentioned that the elytra had "regular series of impressed punctures." La Ferté did not see any of Say's specimens but did have a series in which the elytra were "finement et irrégulièrement ponctuées." For this series he proposed the name interruptus. Casey segregated specimens in his series under the two names already in use on the basis of whether the punctures became "abruptly coarse and distinctly seriate in basal third or fourth" of the elytra or "very gradually coarse and confusedly subserial in arrangement toward base." In addition he described a third species, impressulus, on the basis of a series with a broader anterior lobe of the prothorax, a feeble median canaliculation on this lobe and other differences.

Subsequent students of the Anthicidae have used these three names and some have been able to identify three species by using Casey's key. I have been unable to use it except to segregate specimens of impressulus. The identified specimens I have seen of the other two are generally referred to constrictus if the elytra are markedly paler at the base and to interruptus if the pale area is more diffuse. Specimens with the elytra entirely pale do not fit either description very well but are most easily referred to constrictus.

My own investigations have convinced me that the distinction in the arrangement of the elytral punctures does not exist. The punctures appear larger and deeper in pale areas but are no different from those in other speci- 
mens in which the same area is dark. The more conspicuous they are, the easier it is to imagine that they are more nearly serially arranged. The distinction is, at best, a subtle one.

An examination of the genitalia of the males indicates that four, not three, very different species occur in the United States, of which impressulus alone is externally distinct. Even this last species is not always very obvious. Specimens of all four vary from pale, through dark with the base of the elytra pale, to all dark.

A nomenclatorial problem immediately presents itself. Both Say and La Ferté very obviously described species of Tomoderus. Say's type specimens have certainly been lost. La Ferté's type series of five specimens may still remain in his collection and he mentions a dozen more in the Dejean collection, sent by LeConte. There is every chance that these series are mixed and it would be necessary to dissect any males and decide on one as a lectotype. Both the La Ferté and the Dejean collection are under the care of the Paris Museum and such an examination is not possible without a visit there.

I have therefore decided to assign the names constrictus and interruptus to our two most abundant species, without formal designation of neotype and lectotype respectively. If there are any males in La Ferté's series, and the species here associated with the name is not represented, it will be within the province of a future investigator to reassign the name interruptus. The same might also be said of bilobus, a Dejean manuscript name mentioned by La Ferté as a color variety of interruptus. Constrictus was described without mention of type locality. Since Say spent more time in Indiana and Pennsylvania than in the South, and since he mentions the locality of other species described in the same paper as having been collected on special trips, the choice made here is consistent with the possible type locality. The species chosen is the abundant one in the Middle Atlantic States and the Midwest. Interruptus was described from specimens collected in Texas by Pilate. Very few specimens of Tomoderus have been seen from Texas and both constrictus and interruptus in 
the interpretation of the present author are represented. The one chosen to bear the name interruptus is by far the more abundant across the South.

The new species described here seems to be the least abundant of the three externally indistinguishable species. It is, of course, possible that it is the only one represented in La Ferté's series. In this event the name proposed here would become a junior synonym of interruptus. The species has not yet been taken in Texas but there is no good reason to suspect that it does not range that far since it is very widely distributed.

There is no area in the eastern United States where only one species of Tomoderus would be expected to occur. The apparent exceptions will doubtless disappear when more specimens are examined. At the present time only inhabilis sp. n. has been identified from New England. Constrictus must occur there as well. It has been taken as far north as northern Wisconsin. Therefore no identifications are possible without males, and the genitalia must be seen before even the males can be identified, except in the case of the more obvious specimens of impressulus. Fortunately, only the tip of the genitalia need be examined and the tip is often extruded. Otherwise, the specimen must be dissected. I have found dissection most easily performed by relaxing the specimen in hot water, removing the abdomen and pulling the genitalia anteriorly through the base of the abdomen with fine forceps. The genitalia need not be cleared for the purpose of identification. Males are easily distinguished in a series by the presence of a flattened, semicircular pygidium, which is completely absent in the females, as in all Anthicidae.

The genitalia are asymmetrical, as can be seen in the figures. They are remarkably constant in shape, and even in size, despite some variation in the size of the entire insect. Structurally, they are totally unlike those of any other Anthicidae examined, lacking a recognizable phallobase (basal piece) and possessing a twisted sclerotized structure internally, presumably associated with the internal sac. I have been unable to homologize any of the parts with those of other Anthicidae. The genitalic dif- 
ferences, coupled with the absence of tibial spurs and a very distinctive body form, set off our species of Tomoderus so strikingly that it is questionable whether they should be included in the Anthicidae.

There is little reason to expand the description of the genus given by Casey (1895, Ann. N.Y. Acad. Sci. $8: 648$ ). The following key to species is based entirely on the male genitalia, since they provide the only completely reliable features for distinguishing species.

1. Genitalia notched near the apex ............2

Genitalia not notched near the apex .......... 3

2. Genitalia very unequally notched near the apex, formed into a hook .............. T. interruptus Laf. Genitalia almost equally, and only feebly, notched near the apex ............... T. constrictus (Say)

3. Genitalia slender, slightly expanded just before apex. T. inhabilis sp. n. Genitalia thick, tapered and slightly constricted just before apex T. impressulus Say.

Tomoderus interruptus La Ferté

Plate 5, Figs. 2, 6

Tomoderus interruptus La Ferté, 1848, Monographie des Anthicus et genres voisins . . .: 97. LeConte, 1852, Proc. Acad. Nat. Sci. Phila. 6: 94. Casey, 1895, Ann. N.Y. Acad. Sci. 8: 648.

Tomoderus interruptus var. $\gamma$ (bilobus Dejean) La Ferté, 1848, op. cit.: 98. Tomoderus abbreviatus Casey, 1895, loc. cit. (lapsus calami in the key to species).

As here interpreted this is the commonest species in Florida, ranging from there west to coastal Texas and

\section{Explanation of Plate 5}

Male genitalia of Tomoderus, Figs. 1-4 in dorsal view as they lie in the abdomen, Figs. 5-8 the same specimens in lateral view; all figures with the posterior end at the top. Fig. 1. T. constrictus (Say), Falls Church, Virginia. Fig. 2. T. interruptus Laf., Harahan, Louisiana. Fig. 3. T. inhabilis sp. n., Iowa City, Iowa. Fig. 4. T. impressulus Csy., Valley of the Black Mts., N. Carolina. Fig. 5. T. constrictus. Fig. 6. T. interruptus. Fig. 7. T. inhabilis. Fig. 8. T. impressulus. 
Psyche, 1957

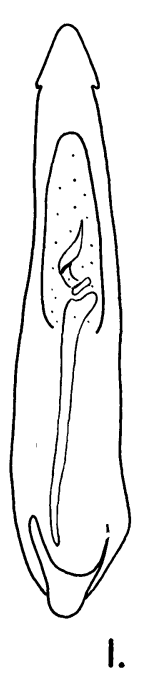

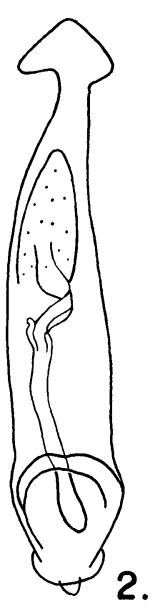

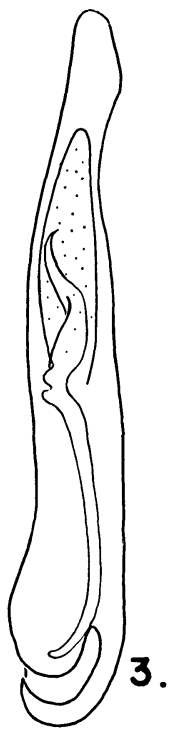

Vol. 64, Plate 5
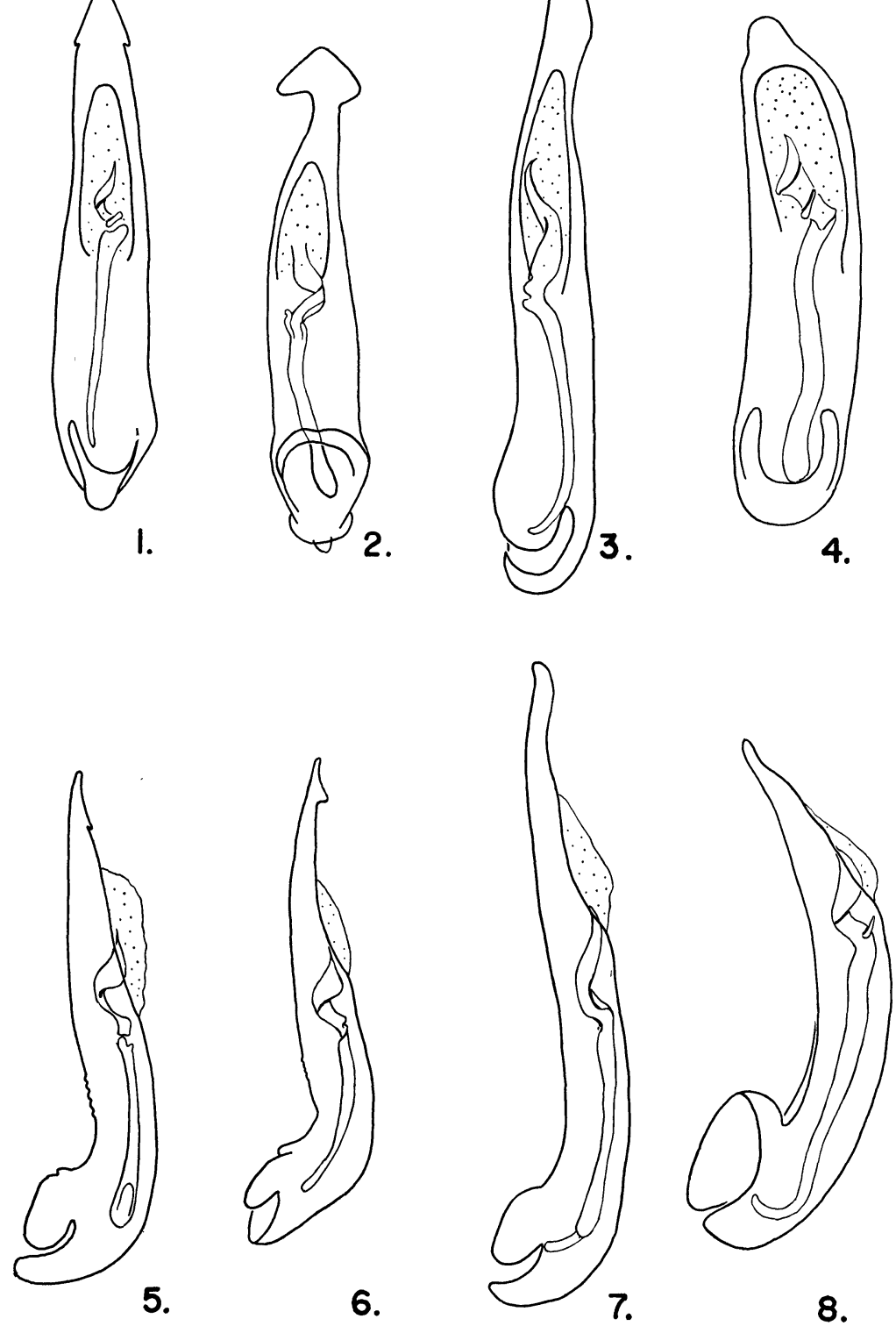

5.

6.

7.

8.
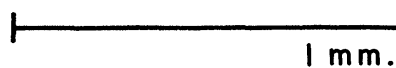

WERNER - TOMODERUS 
north in the Mississippi basin to Indiana. La Ferté mentions that the specimens in his collection were collected in Texas by Pilate and that the Dejean collection contained specimens sent by Leconte. Considering the date of the publication, it is most likely that the specimens were sent by the elder LeConte. In this event they most likely would have been collected in Georgia. Both eastern Texas and Georgia are within the range of the species as here understood, although no specimens collected in Georgia have been examined.

Specimens examined have come from the following localities: Alabama: Central Mills, Jan. 25, 1928, Woodruff. FloRIDA: Ch. Hbr.; DeLand; Jacksonville, July, 1943, G. S. Hensill; Lake Placid, Mar. and April; Lake Wambirg, Mar.; Orlando, Mar.; Ormond; Sand Pt., Feb.; Winter Park. IndianA: Vermillion Co., Aug. 17, W. S. Blatchley. Louisiana: Harahan, Oct., Nov., 1944, at light, F. Werner; New Orleans, Oct. 23, H. Soltau. Tennessee: Memphis, July 3, 1899, Psota Coll. Texas: Richmond, Brazos R., June 22, 1917, J. C. Bradley.

\section{Tomoderus constrictus (Say)}

\section{Plate 5, Figs. 1, 5}

Anthicus constrictus Say, 1827, Journ. Acad. Nat. Sci. Phila. 5: 244. Tomoderus constrictus, La Ferté, 1848, op. cit.: 101. LeConte, 1852, op. cit.: 94. Casey. 1895, op. cit.: 649.

This is the most abundant species from New Jersey to Virginia, west to Illinois and Arkansas. It ranges more widely than this, from New Jersey to Florida west to northern Wisconsin and coastal Texas. It has not yet been identified from New England.

Specimens examined have come from the following localities: ARKAnsas: Carlisle, Feb., 1891, Stromberg; Jasper, Newton Co., Aug. 21, 1948, at light, W. Nutting \& F. Werner; 9 mi. E. Rogers, Benton Co., July 6, 1949, M. W. Sanderson and L. Stannard; Washington Co., Aug. 12, 1939, M. W. Sanderson. D.C. : Blanchard Coll. Florida: Dunedin, Feb. 18, 1929, W. S. Blatchley. ILLINOIS: Galesburg; Oakwood, Oct., ground cover; Putnam 
Co., Apr. 9, 1933; Volo, Oct. 7, 1933, Asterlund, moss in bog. IndianA : Evansville, June 27, 1943, H. S. Dybas; Starke Co., Aug. 14, 1920, W. S. Blatchley. Louisiana: Tallulah, P. A. Glick. MarYlaND: Baltimore, Mar. 14. MissourI : St. Louis. NeW JERSEY : Arlington, E. L. Dickerson; Emerson, Feb. 3, 1918, Quirsfeld. NEW YoRK: Staten Island, Feb. OHIo: Cincinnati; Holgate; Holmes Co., Feb., Mar., Everly; Holmesville, Mar. 24, 1928; Marietta, Nov. 10 ; Mendon, Mercer Co., Aug.; Salineville, Feb. 4, 1891. Pennsylvania: Angora, June 15, G. M. Greene; Easton, May 4, 1937, J. W. Green. South Carolina : Sumter, Oct. 20, 1926. Texas: Lee Co., July, 1912, J. C. Warren. Virginia: Falls Church, Sept. 28, Nov. 18, N. Banks. Wisconsin : Bayfield Co., Liebeck Coll.

Tomoderus inhabilis sp. n.

Plate 5, Figs. 3, 7

This species is externally almost indistinguishable from Tomoderus interruptus and T. constrictus as interpreted in the present paper. The antennae tend to be slightly thicker toward the apex than in either of these two species. The following measurements, in $0.01 \mathrm{~mm}$., length over maximum width, from basal to apical segments, show a comparison of the antennae of a male of each of the four species. It has not proven practical to segregate the species on this basis. Interruptus: $15 / 9,10 / 6,11 / 6$, $10 / 6,11 / 7,10 / 8,11 / 10,11 / 10,11 / 12,10 / 12,14 / 12$. Constrictus : $13 / 9,8 / 6,9 / 6,9 / 6,10 / 7,10 / 7,11 / 8,11 / 9,10 / 10$, $10 / 10,13 / 10$. Inhabilis: $15 / 8,11 / 6,11 / 6,10 / 7,12 / 9$, $11 / 10,11 / 11,11 / 11,11 / 12,10 / 13,16 / 12 . \quad$ Impressulus: $15 / 9,10 / 7,11 / 7,10 / 8,11 / 9,10 / 9,9 / 11,9 / 12,9 / 13,9 / 13$, $13 / 12$. Segments VII to $\mathrm{X}$ are at least as broad as long in these specimens of impressulus and inhabilis, while only segments IX and X are as broad as long in the other two species. Even though these differences are not constant enough or striking enough for identification of species, they show up fairly well in a series after the specimens have been identified on the basis of the male genitalia. Except in the case of impressulus, where the thickness of the antennae can be associated with other external 
characters, antennal differences are probably not reliable enough for the identification of female specimens.

The male genitalia are distinctive, considerably more slender than in the other Nearctic species, and slightly expanded on one side near the apex, without any definite notches on the sides. Because they are dorso-ventrally flattened, they are more similar to those of interruptus and constrictus than they are to those of impressulus. The figures should be consulted for comparison.

Inhabilis ranges very widely east of the 100th Meridian, from Massachusetts to Florida, west to eastern Kansas and Arkansas. It has not yet been taken in coastal Texas. Despite the wide range, it has not been found to be abundant at any locality.

Type series: All the specimens designated as types are males in which the genitalia have been examined. Holotype: Homestead, Florida, June, 1929, P. J. Darlington (MCZ). Paratypes: ARKANsas: 2 Washington Co., Oct. 11, 1939, M. W. Sanderson (INHS and author). ConNECTICUT: 1 So. Meriden, Apr. 9, 1939, H. L. Johnson (Conn. Ins. Surv.). FloRIDA: 2 Alachua Co., Apr. 24, 1948, I. J. Cantrall (U. Mich. and author). 1 Ch. Hbr., A. T. Slosson (AMNH). Enterprise, June 19, Bowditch Coll. (MCZ). 2 Homestead, eutopotypical (MCZ and author). Jacksonville, A. T. Slosson (AMNH). Titusville, Mar. 21/22, 1939, F. E. Lutz (AMNH). Georgia: 1 Spring Ck., Decatur Co. Jul. 16-29, 1912 (Cornell). IndianA: 1 Vermillion Co., Aug. 17, 1921, W. S. Blatchley (Cornell). 1 Vigo Co., May 30, 1907, A. B. Wolcott (Chicago Nat. Hist. Mus.). IowA: 2 Iowa City, Mar. 25, 1898, H. F. Wickham (MCZ and author). Kansas: 1 Riley Co., Mar. 13, Popenoe (Kans. State). 2 Topeka, Popenoe (USNM and Kans. State). MASSACHUSETTS : 1 Tewksbury, Sept. 2, 1871, F. Blanchard (MCZ). Mississippi : 1 Lucedale, Dec. 4, 1930, H. B. Dietrich (Cornell). Missouri: 1 St. Louis, Liebeck Coll. (MCZ).

\section{Tomoderus impressulus Casey}

Plate 5, Figs. 4, 8

Tomoderus impressulus Casey, 1895, op. cit.: 649.

Samples of this species from the southern Appalachians 
are easily recognizable by their generally dark color, thickened antennae and slightly broader anterior lobe of the prothorax, this lobe having a fine median groove. Samples from other areas are not as obvious. The general color may be paler, the antennae not so obviously thickened and the anterior lobe of the pronotum not canaliculate. Specimens from other areas than the Appalachians are most easily identified by the form of the male genitalia, as shown in the key and figures.

This is apparently the common species in the southern Appalachians but it is apparently rather scarce elsewhere in its range. Specimens have been seen from coastal South Carolina, Virginia, Indiana, Illinois, eastern Kansas and a single specimen from the state of Washington. The combination of the southern Appalachians and Washington in its distribution suggests a relict distribution such as has been noted in some other groups of insects. No other species is known from west of the 100th Meridian in North America. The Washington specimen was taken by G. H. Nelson, an entomologist known for his attention to detail. There can be no question that the locality label is correct.

Specimens have been examined from the following localities: IllinoIs: White Heath, Piatt Co., Apr. 1, July 20, Sept. 23, Oct. 12, Oct. 29, No. 7, in soil and humus, J. C. Dirks. Indiana: Vermillion Co., Aug., W. S. Blatchley. Kansas: Atchison, Apr. 25, H. Soltau; Topeka, Sept. 10, 1942, C. H. Seevers. NorTh CARolina: Asheville (type locality) ; L. Toxaway, A. T. Slosson; Valley of the Black Mountains, July, Sept. 24 and 30, 1900, Aug., Sept. 10-14, 1906, W. Beutenmuller. South CARolina: Florence, Jan. 18. VIRGINIA : Fairfax Co., Sept., Quirsfeld. WASHINGTON : Deep Lake, (Douglas Co.), May 5, 1949, G. H. Nelson. 

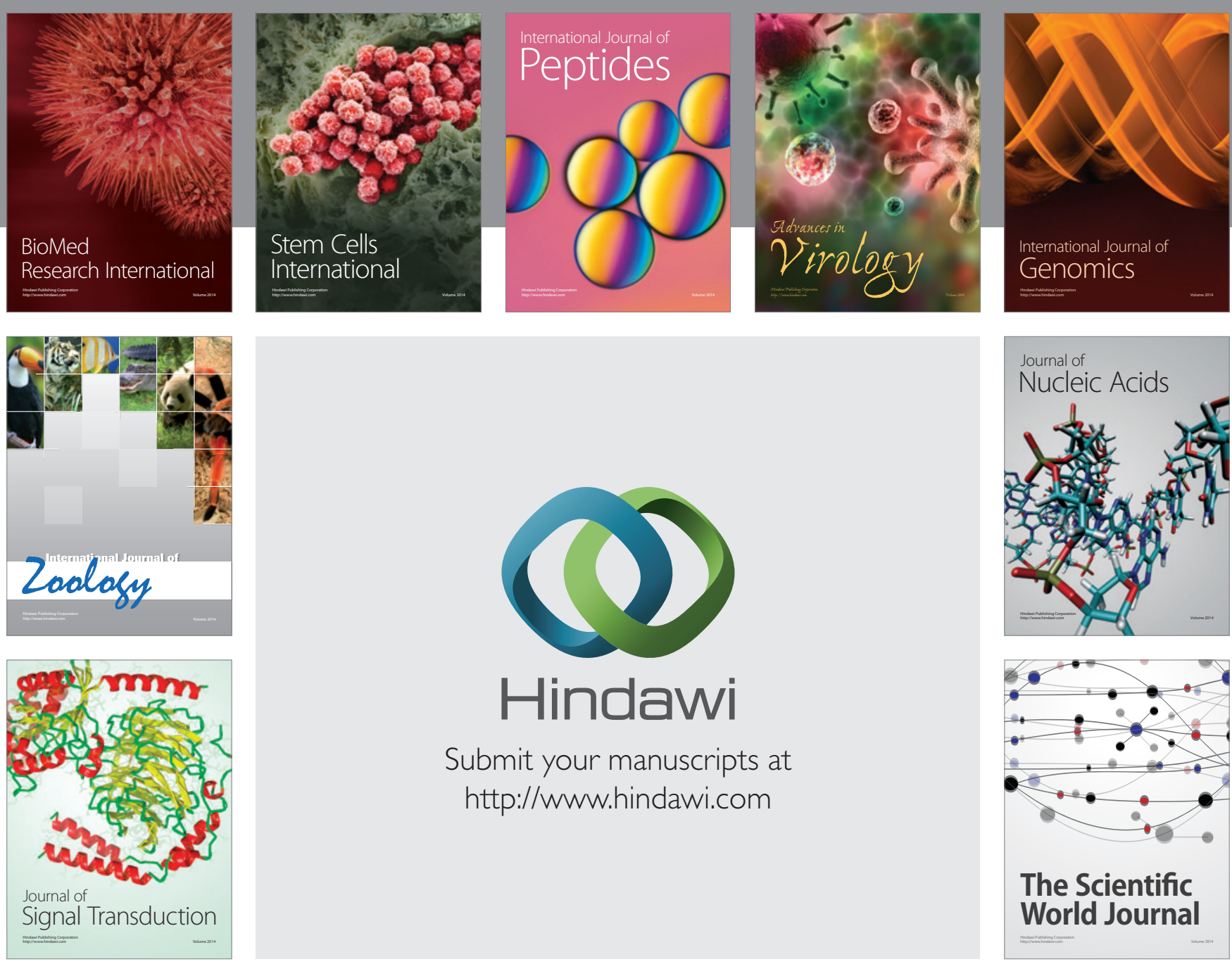

Submit your manuscripts at

http://www.hindawi.com
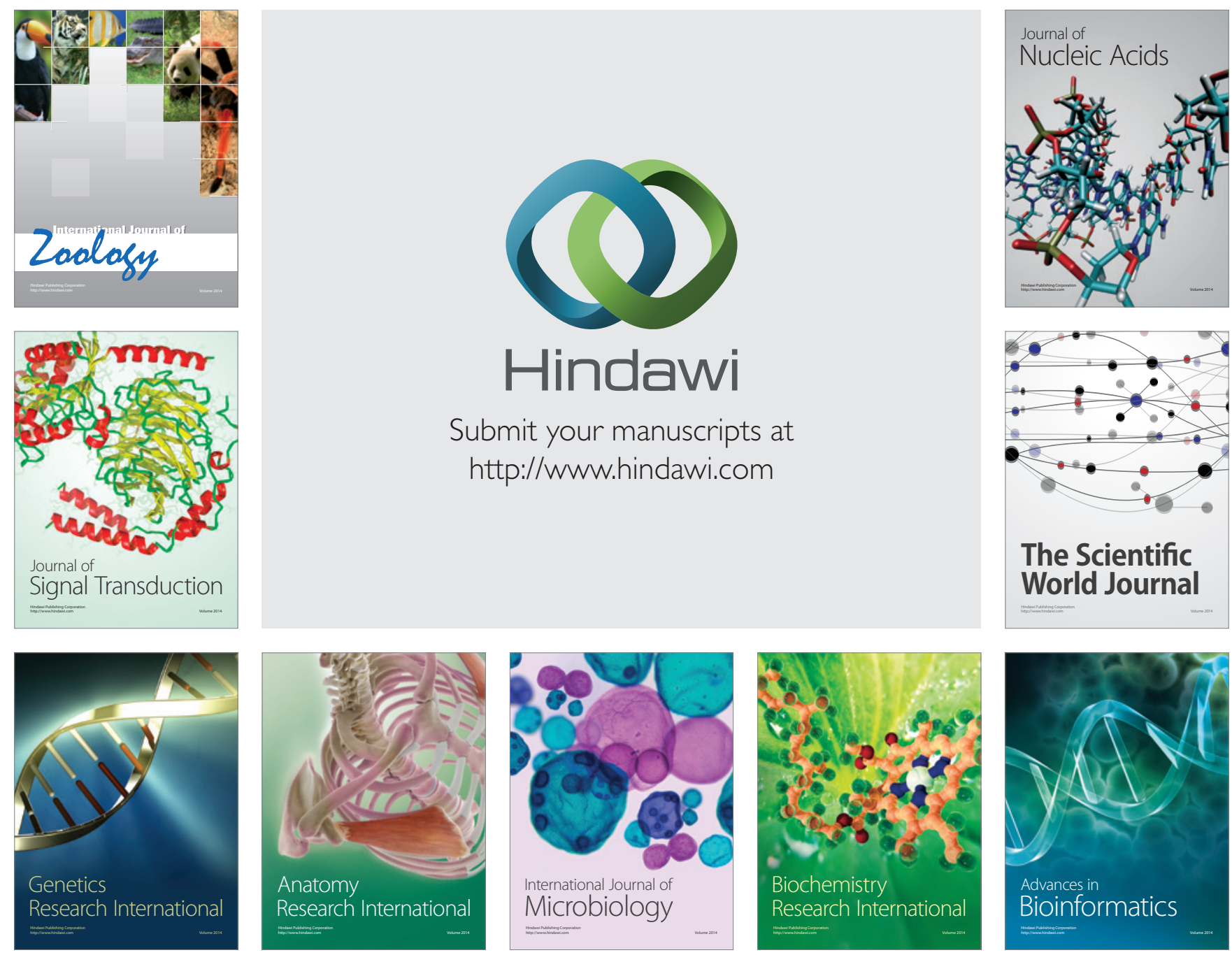

The Scientific World Journal
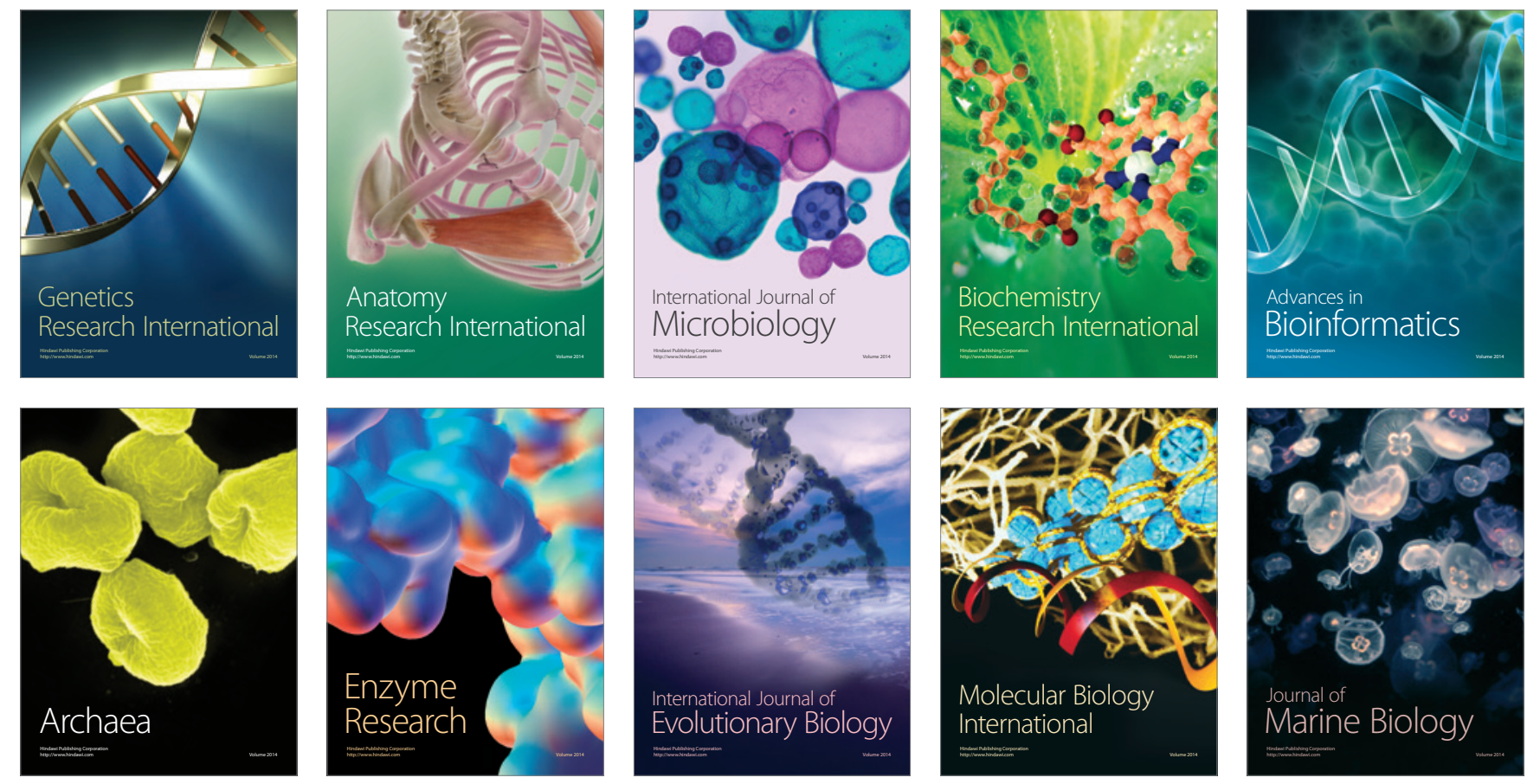